\title{
Periostin localizes to cells in normal skin, but is associated with the extracellular matrix during wound repair
}

\author{
Linda Jackson-Boeters • Weiyan Wen • \\ Douglas W. Hamilton
}

Received: 15 April 2009 / Accepted: 20 May 2009/Published online: 19 June 2009

(C) The Author(s) 2009. This article is published with open access at Springerlink.com

\begin{abstract}
Epidermal tissue repair represents a complex series of temporal and dynamic events resulting in wound closure. Matricellular proteins, not normally expressed in quiescent adult tissues, play a pivotal role in wound repair and associated extracellular matrix remodeling by modulating the adhesion, migration, intracellular signaling, and gene expression of inflammatory cells, pericytes, fibroblasts and keratinocytes. Several matricellular proteins show temporal expression during dermal wound repair, but the expression pattern of the recently identified matricellular protein, periostin, has not yet been characterized. The primary aim of this study was to assess whether periostin protein is present in healthy human skin or in pathological remodeling (Nevus). The second aim was to determine if periostin is expressed during dermal wound repair. Using immunohistochemistry, periostin reactivity was detected in the keratinocytes, basal lamina, and dermal fibroblasts in healthy human skin. In pathological nevus samples, periostin was present in the extracellular matrix. In excisional wounds in mice, periostin protein was first detected in the granulation tissue at day 3, with levels peaking at day 7. Periostin protein co-localized with $\alpha$ smooth muscle actin-positive cells and keratinocytes, but not CD68 positive inflammatory cells. We conclude that periostin is normally expressed at the cellular level in human and murine skin, but additionally becomes extracellular during tissue remodeling. Periostin may represent a
\end{abstract}

L. Jackson-Boeters $\cdot$ W. Wen $\cdot$ D. W. Hamilton $(\bowtie)$

CIHR Group in Skeletal Development and Remodeling,

Division of Oral Biology,

Schulich School of Medicine and Dentistry,

The University of Western Ontario,

Dental Sciences Building,

London, ON, CanadaN6A 5C1

e-mail: dhamil2@uwo.ca new therapeutic target for modulating the wound repair process.

Keywords Periostin - Skin - Wound repair.

Extracellular matrix $\cdot$ Keratinocytes $\cdot$ Myofibroblasts

\section{Introduction}

Periostin comprised of 811-amino acids has been recently classed as a matricellular protein (Hamilton 2008; Norris et al. 2008a). Unlike many other members of the matricellular protein family, periostin is expressed in adults, most commonly in collagen-rich tissues (Hamilton 2008), where its expression is often associated with fibroblasts (Tilman et al. 2007). Analysis of the periostin null mouse suggests that periostin is fibrogenic, as significant abnormalities in the atrioventricular valve points to a role for periostin in the differentiation of the cushion mesenchyme into myofibroblastic-valve tissue (Butcher et al. 2007; LieVenema et al. 2008; Norris et al. 2008b). Periostin has also been shown to be prominently upregulated during extracellular matrix (ECM) remodeling, including after myocardial infarction (Kuhn et al. 2007; Shimazaki et al. 2008), in bone marrow fibrosis (Oku et al. 2008) and during pulmonary vascular remodeling (Chen et al. 2006). It therefore appears that periostin is an important regulator of fibroblast differentiation and ECM remodeling in both normal and pathological tissues.

The excisional full thickness dermal wound model is a powerful tool for understanding how individual proteins contribute to the wound repair process (Basu et al. 2001; Cowin et al. 2001; Jarvelainen et al. 2006). While collagens, fibrin and fibronectin provide structural support during dermal wound repair, it is has been shown that 
matricellular proteins act temporally and spatially to modulate the adhesion, proliferation and differentiation of inflammatory cells, fibroblasts, pericytes, and endothelial cells (Midwood et al. 2004). Matricellular proteins including galectins (Elola et al. 2007), thrombospondins (Puolakkainen et al. 2005), syndecans (Midwood et al. 2004), SPARC (Reed et al. 1993) and tenascin-C (Latijnhouwers et al. 1996) appear in the provisional matrix and influence matrix deposition, angiogenesis, cell maturation and wound contraction up to 15 days post injury. At the onset of late inflammation and the initiation of the proliferative phase of wound repair (days 5-7), fibroblasts migrate through the loose granulation tissue matrix, which is composed of collagen types I, III and IV, fibrin, fibronectin and hyaluronan (Agren and Werthen 2007). Concurrent with this migration, fibroblasts undergo a phenotypic change, becoming $\alpha$-smooth muscle actin ( $\alpha$-SMA)-expressing myofibroblasts, facilitating contraction of the wound edge (Desmouliere et al. 2005; Gabbiani 2003). Given that it appears to be pro-fibrogenic, we hypothesized that periostin would be expressed in granulation tissue formed in response to experimentally induced excisional wounds. However, whether periostin is expressed in dermal wound repair has yet to be shown.

The aim of this study was two fold: 1) to determine if periostin is expressed in healthy and pathological human skin and; 2) to assess the expression and localization of periostin during excisional dermal wound repair. Using immunhistochemistry, we identified that periostin is expressed in normal human and murine skin. Furthermore, periostin is expressed in the remodeling ECM formed during wound repair where it is associated with myofibroblasts. We conclude that periostin is expressed in healthy skin as well as in ECM remodeling in response to pathology and dermal wound repair.

\section{Materials and methods}

Animals

All studies involving mice were performed in compliance with the University Council on Animal Care at the University of Western Ontario under approved protocols. Serological analyses were performed on the mice prior to experiments to test for the presence of blood borne pathogens or infection. For experiments, mice were housed in individual cages and maintained under a $12 \mathrm{~h}$ light/dark cycle and temperature in accordance with the guidelines of the Canadian Council on Animal Care. For wounding experiments, eight male C57/BL6 mice (7-8 weeks of age weighing approximately $25 \mathrm{~g}$ ) were anesthetized with an intraperitoneal injection containing ketamine $(75 \mathrm{mg} / \mathrm{kg}$ ) and xylazine $(5 \mathrm{mg} / \mathrm{kg})$. The backs were cleaned, shaved, and sterilized with betadine solution. Two full-thickness wounds through the epidermis and dermis were made on both sides of the dorsal midline, using a $5 \mathrm{~mm}$ punch biopsy. Animals were sacrificed at 0, 3, 7, 21 and 28 days post wounding for histological analysis.

\section{Sample preparation and immunohistochemistry}

Formalin fixed, paraffin embedded skin and nevus samples were drawn from the archives of the Oral Pathology Diagnostic Service, University of Western Ontario. Skin samples from mice were prepared, fixed and embedded as previously described (Leask et al. 2008). The specimens were examined for the expression of periostin using standard in situ immunohistochemical techniques. $5 \mu \mathrm{m}$ sections were cut from each block using a microtome and placed on positively charged slides (Fisher scientific), which were dried overnight in an oven at $42^{\circ} \mathrm{C}$. To stain sections for periostin, sections were rehydrated and then quenched in 3\% hydrogen peroxide in methanol for $5 \mathrm{~min}$. Each section was then rinsed in $\mathrm{H}_{2} \mathrm{O}$, followed by phosphate buffered saline (PBS) for $5 \mathrm{~min}$. Sections were blocked with $10 \%$ horse serum in PBS for $30 \mathrm{~min}$ at room temperature in a humidified chamber. Excess horse serum was removed and sections were incubated with goat antihuman periostin antibody (periostin S-15: sc-49480, Santa Cruz Biotechnology, Inc.) at $1 / 200$ dilution overnight at $4^{\circ} \mathrm{C}$ in a humidified chamber. $10 \%$ horse serum with no primary antibody was used as a control for each sample. Following incubation, sections were rinsed in PBS for $5 \mathrm{~min}$. Rinsed sections were then incubated with ImmPress AntiGoat Ig (Vector laboratories) for $30 \mathrm{~min}$ at room temperature in humidified chamber, followed by a 5-minute wash in PBS. Sections were visualized using the DAB substrate kit for perioxidase (Vector Laboratories). The reaction was stopped by rinsing sections in $\mathrm{H}_{2} \mathrm{O}$. The sections were then counterstained in Harris hematoxylin for $1 \mathrm{~min}$, rinsed in tap water, and blued in ammonium alcohol. Sections were then rinsed with tap $\mathrm{H}_{2} \mathrm{O}$, and dehydrated by bringing them from water through to xylene. Sections were coverslipped using Cytoseal (VWR). Slides were analyzed under light microscopy.

Culture of human dermal fibroblasts

Human dermal fibroblasts were isolated using an explant technique as previously described (Chen et al. 2008). In brief, explants were cultured on tissue-culture plastic in alpha minimal essential medium (Stem cell Technology, Vancouver, BC, Canada) supplemented with antibiotics penicillin G, $100 \mathrm{mg} / \mathrm{ml}$ (Sigma, St. Louis, MO); gentamicin, $50 \mathrm{mg} / \mathrm{ml}$ (Sigma); Fungizone, $3 \mathrm{mg} / \mathrm{ml}$ (Gibco, Grand Island, NY); and $15 \%$ fetal bovine serum (Flow, McLean, 

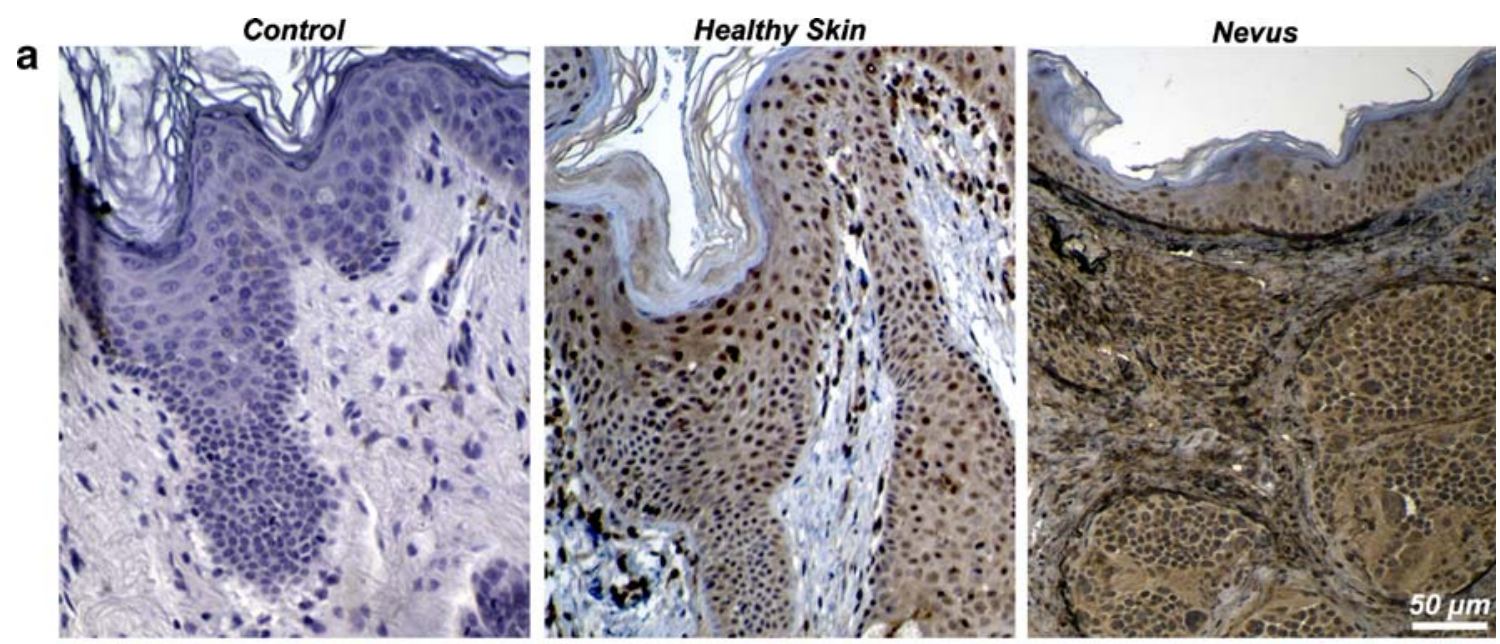

b
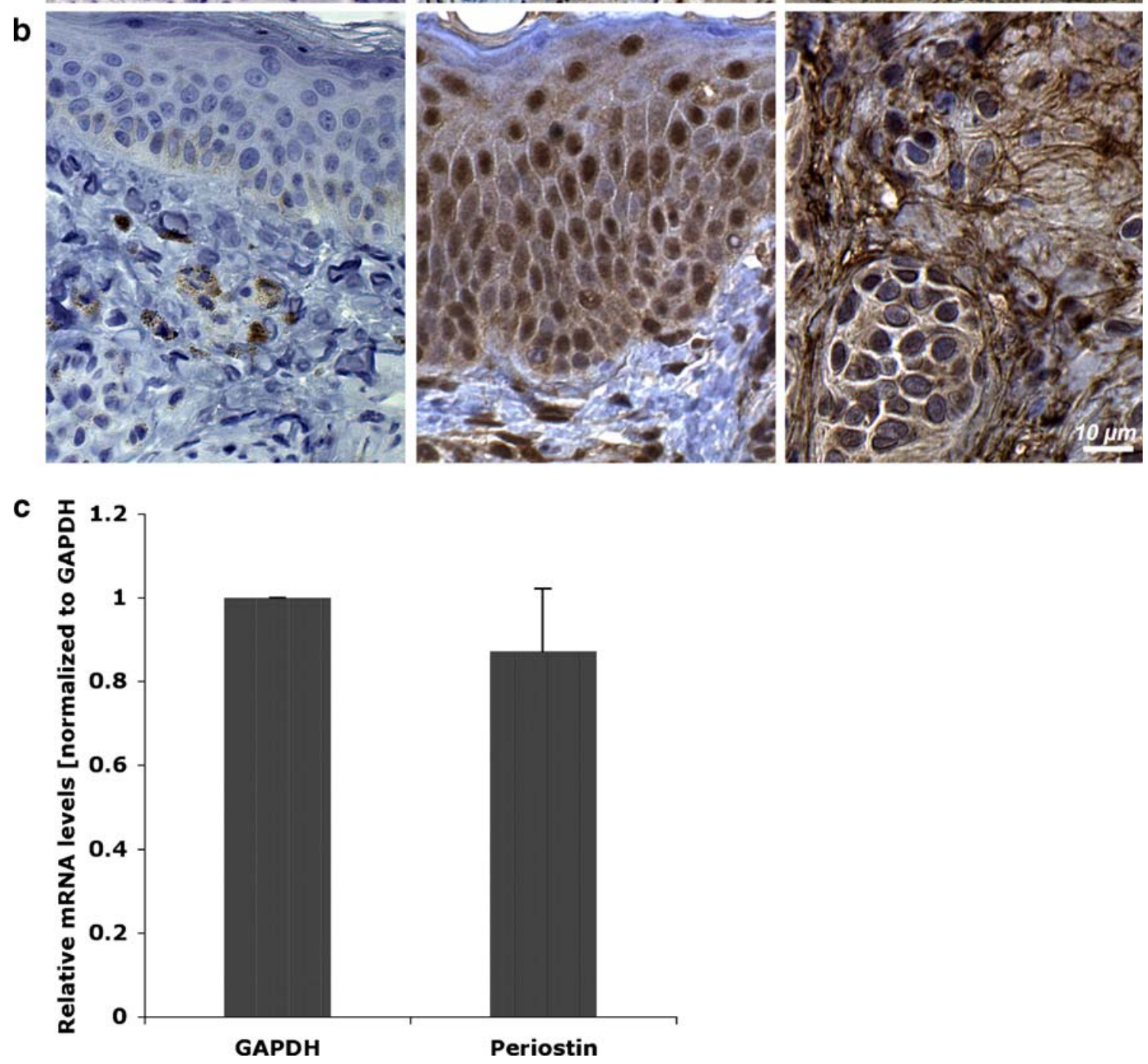

Fig. 1 Periostin is expressed in healthy and pathological human skin samples. a In healthy skin, periostin is associated with dermal fibroblasts and keratinocytes, but in nevus, periostin localizes within the

extracellular matrix, which is further evident at higher magnifications shown in (b). Confirmation of periostin mRNA levels in human dermal fibroblasts using Taqman polymerase chain reaction is shown in (c) 
VA) at $37^{\circ} \mathrm{C}$ in a humidified atmosphere of $95 \%$ air $5 \%$ $\mathrm{CO}_{2}$. Once confluent, cells were removed from the growth surface using a trypsin solution $[0.25 \%$ trypsin (Gibco), $0.1 \%$ glucose, citrate-saline buffer $(\mathrm{pH} 7.8)]$. Cells were used between passage $2-5$ for experiments.
Taqman realtime polymerase chain reaction

Total RNA was isolated using Trizol reagent (Invitrogen). Total RNA (25 ng) was amplified using the TaqMan One Step RT-PCR Master Mix (4309169; Applied Biosystems

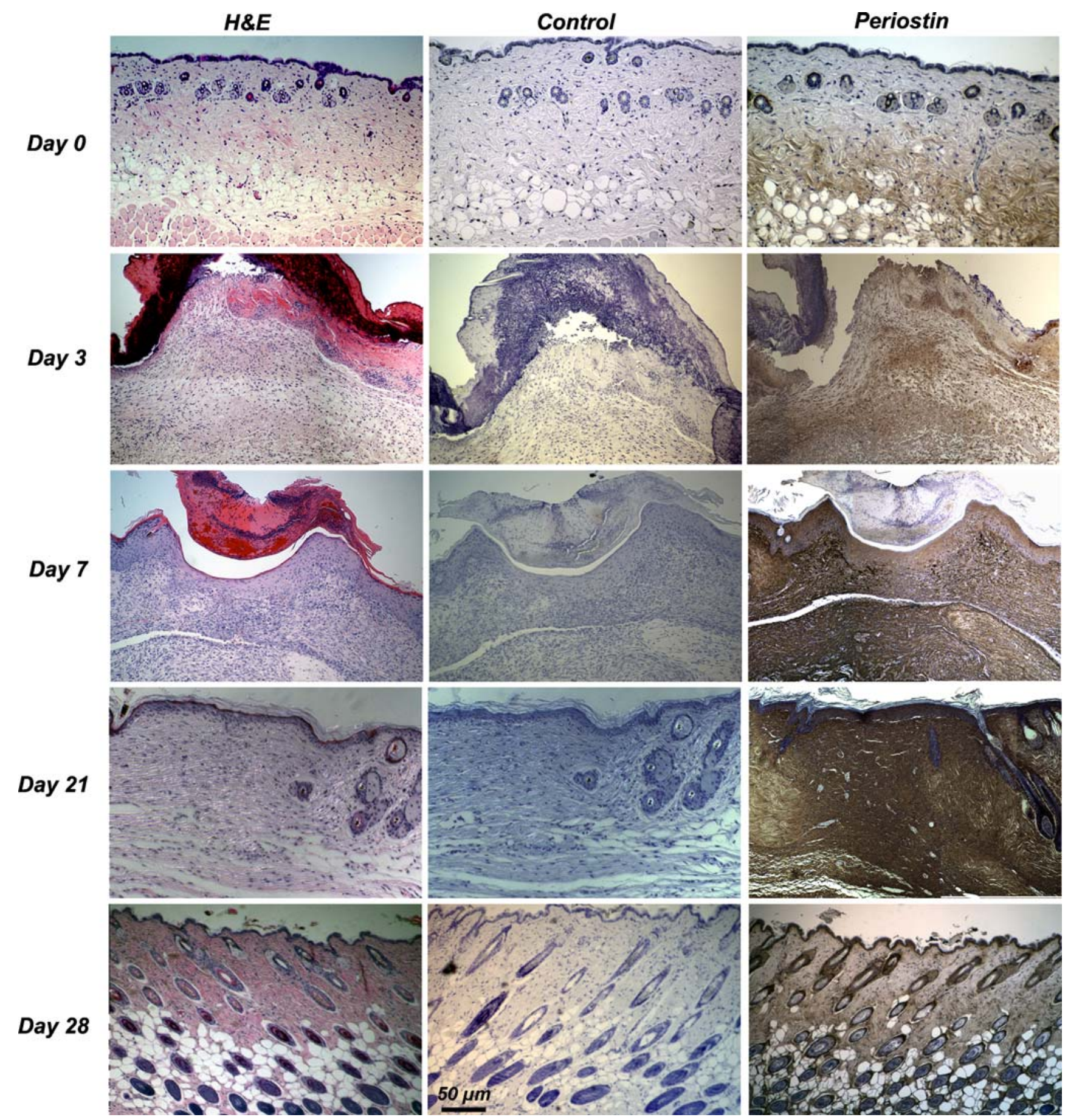

Fig. 2 Immunohistochemical staining of periostin at 0, 3, 7, 21 and 28 days post wounding with a polyclonal antibody to periostin. Periostin expression is evident in the granulation tissue at 3 days, with levels peaking at 7 days. At day 7, the granulation tissue undergoes remodeling and the wound begins to contract, suggesting a role for periostin in both processes 
Inc., Streetsville, ON, Canada). Reverse transcription and quantitative real-time PCR reactions were performed using the Prism 7900 HT Sequence Detector (Applied Biosystems Inc.). Samples were incubated at $48^{\circ} \mathrm{C}$ for $30 \mathrm{~min}$ to make cDNA templates. The resulting cDNA was amplified for 40 cycles. Cycles alternated between $95^{\circ} \mathrm{C}$ for $15 \mathrm{~s}$ and $60^{\circ} \mathrm{C}$ for $1 \mathrm{~min}$. Results were analysed using SDS v2.1 software (Applied Biosystems Inc.). The $\Delta \Delta \mathrm{Ct}$ method was used to calculate gene expression levels relative to GAPDH and normalized to control cells. Data were logtransformed prior to analysis by one-way analysis of variance and Tukey's post-hoc test, using Graphpad Software v. 4 (Graphpad Software, La Jolla, CA, USA).

\section{Results}

Periostin localization in healthy human dermis and nevus

Using immunohistochemistry, we examined the localization of periostin in healthy human skin and in nevus tissue, the latter representing pathological remodeling of skin. In healthy skin, periostin was detected predominantly in the epidermis, where it localized to the nucleus of the keratinocytes (Fig. 1a, b). Mature keratinocytes in the outer epidermis did not stain positively for periostin. Fibroblasts in the dermis also exhibited reactivity for periostin, which we confirmed in cultured dermal fibroblasts using realtime PCR for periostin mRNA (Fig. 1c). In nevus samples, the localization of periostin was similar in the epidermal layer to normal skin, but in the remodeled dermis, periostin was detected predominantly in the extracellular matrix, where periostin associated with large fibrils around the cells (Fig. 1b).

Expression and localization of periostin in full thickness dermal wounds

To assess the role of periostin in dermal wound repair, we created full thickness dermal wounds in C57/BL6 mice using a $5 \mathrm{~mm}$ biopsy punch (Figs. 2 and 3). In unwounded skin (Day 0), periostin was detected in the hypodermis, around hair follicles, as well as in the basal lamina. Periostin reactivity was evident in a subset of keratinocyte nuclei. After wounding, periostin reactivity was first evident in the granulation tissue at day 3, with higher levels evident in the migrating keratinocytes at the edge of the wound, particularly associated with the nucleus. At day
Fig. 3 Immunohistochemical staining of periostin at $0,3,7$, 21 and 28 days post wounding with a polyclonal antibody to periostin. White arrows denote nuclear localization of periostin. Periostin expression is first evident in the granulation tissue and keratinocytes at 3 days, with levels peaking at 7 days and returning to basal levels at 28 days

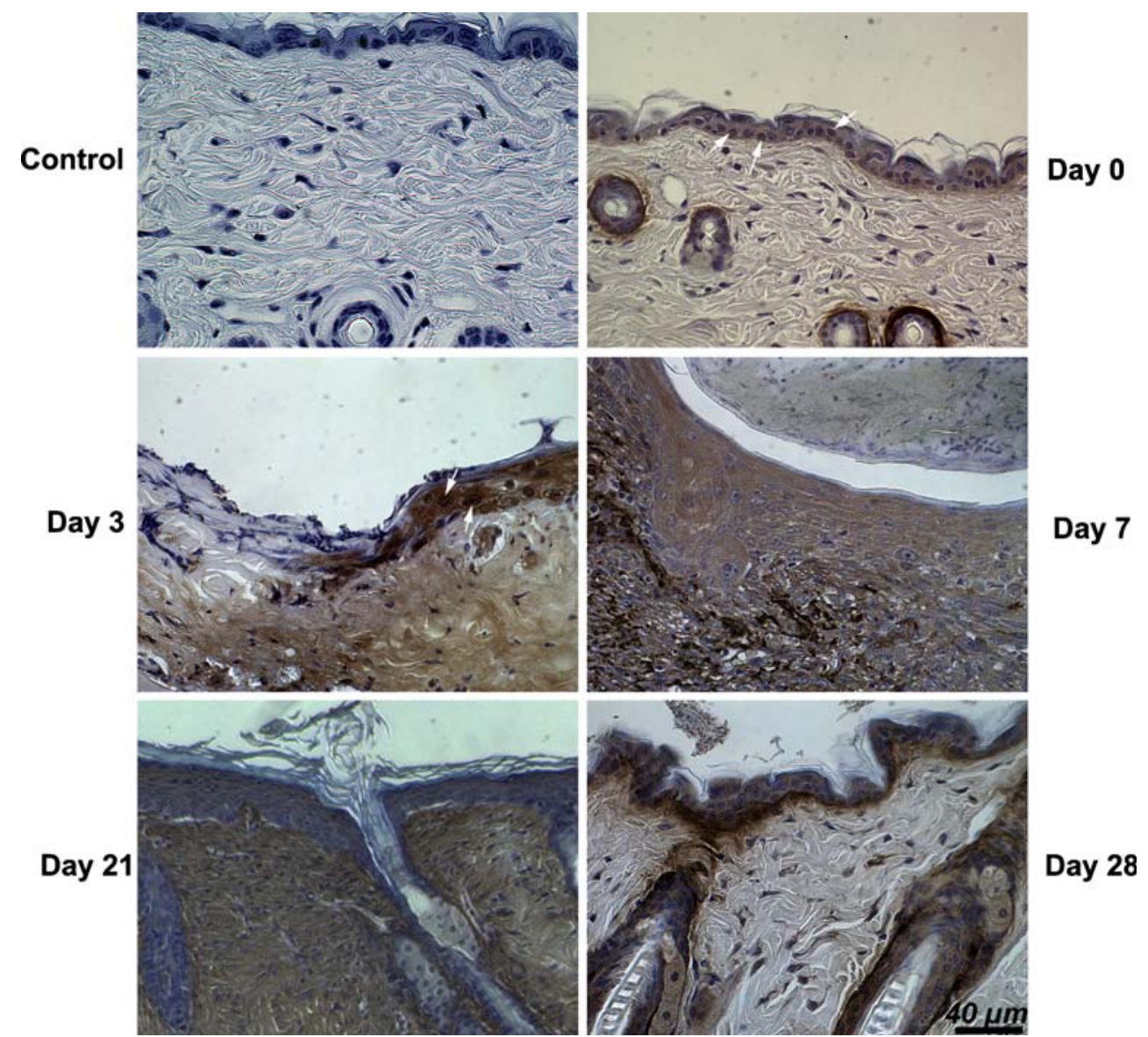


7, migrating keratinocyes, which had already reepithelialized the wound, were highly reactive for periostin protein. Furthermore, periostin protein was present in the ECM of the remodeling dermis/granulation tissue. At day 21, periostin staining was evident only in the remodeling matrix. Periostin protein levels returned to day 0 levels at day 28 post-wounding.

Periostin expression correlates with an increase in $\alpha$-SMA

As periostin has been previously associated with differentiation of cushion mesenchyme into myofibroblastic valve tissue (Norris et al. 2008b), we assessed whether periostin protein in the remodeling granulation tissue and ECM was associated with the presence of $\alpha$-SMA associated myofibroblasts. At day 3, although periostin expression was evident in the granulation tissue at low levels, only a few $\alpha$ SMA-positive myofibroblasts were detected migrating into the tissue (Fig. 4a, b). The majority of cells in the granulation tissue were $\mathrm{CD} 68$ positive denoting them as macrophages (Fig. 4c, d). At day 7 where periostin protein levels were highest, a significant increase in $\alpha$-SMA was evident (Fig. 5a-c), which also corresponded to the areas in the wound bed where periostin expression was highest.

\section{Discussion}

Periostin is a secreted extracellular matrix protein, that has been hypothesized to promote fibrogenic differentiation (Erkan et al. 2007; Norris et al. 2008a). In humans, periostin expression is variable in normal healthy tissues, but is most commonly associated with fibroblast-rich tissues (Tilman et al. 2007). In this present study, we report that periostin protein is expressed in both healthy and pathological human and murine skin. Furthermore, periostin is a significant component of the granulation tissue and remodeling ECM formed during the repair of excisional dermal wounds, where periostin is associated with $\alpha$-SMA myofibroblasts and keratinocytes.
Fig. 4 Periostin, $\alpha$-SMA, and CD68 localization at 3 days post wounding. a and $\mathbf{b} \alpha$-SMA associated fibroblasts can be seen migrating into the granulation tissue, with low levels of periostin evident in the same area (White arrows denote areas of fibroblast migration). $\mathbf{c}$ In other areas of the matrix not associated with periostin expression, CD68 positive cells are present which are cells of the macrophage lineage

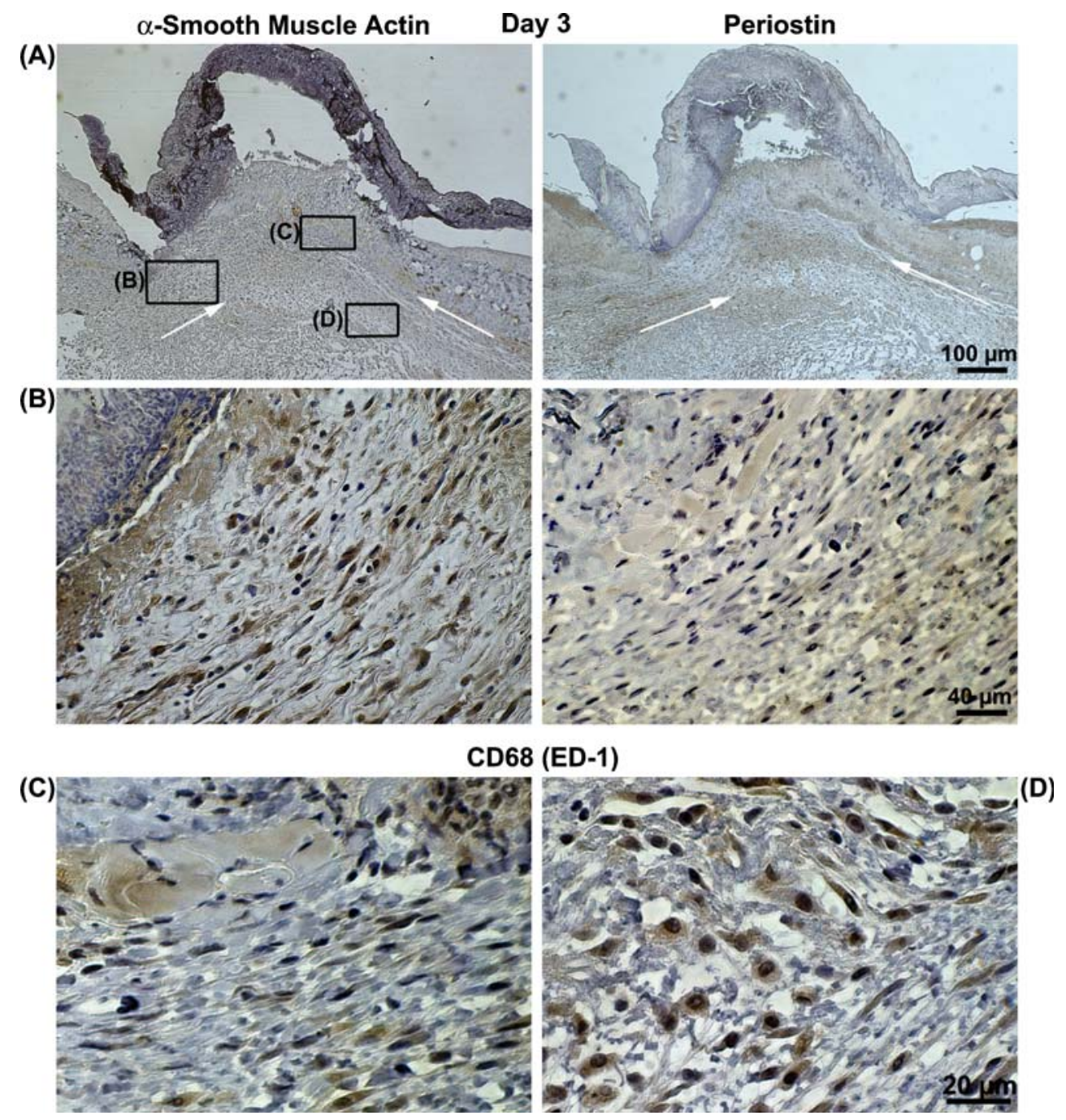


Fig. 5 Periostin and $\alpha$-SMA localization in dermal wounds at 7 days post wounding. a At low magnifications, $\alpha$-SMA is evident throughout the wound bed, as is periostin protein. At higher magnifications, $\alpha$-SMA positive myofibroblasts and periostin localize to $\mathbf{b}$ the area under the epithelium, as well as in $\mathbf{c}$ lower areas of the dermis. In b white arrows indicate $\alpha$-SMA positive cells in the epithelial layer

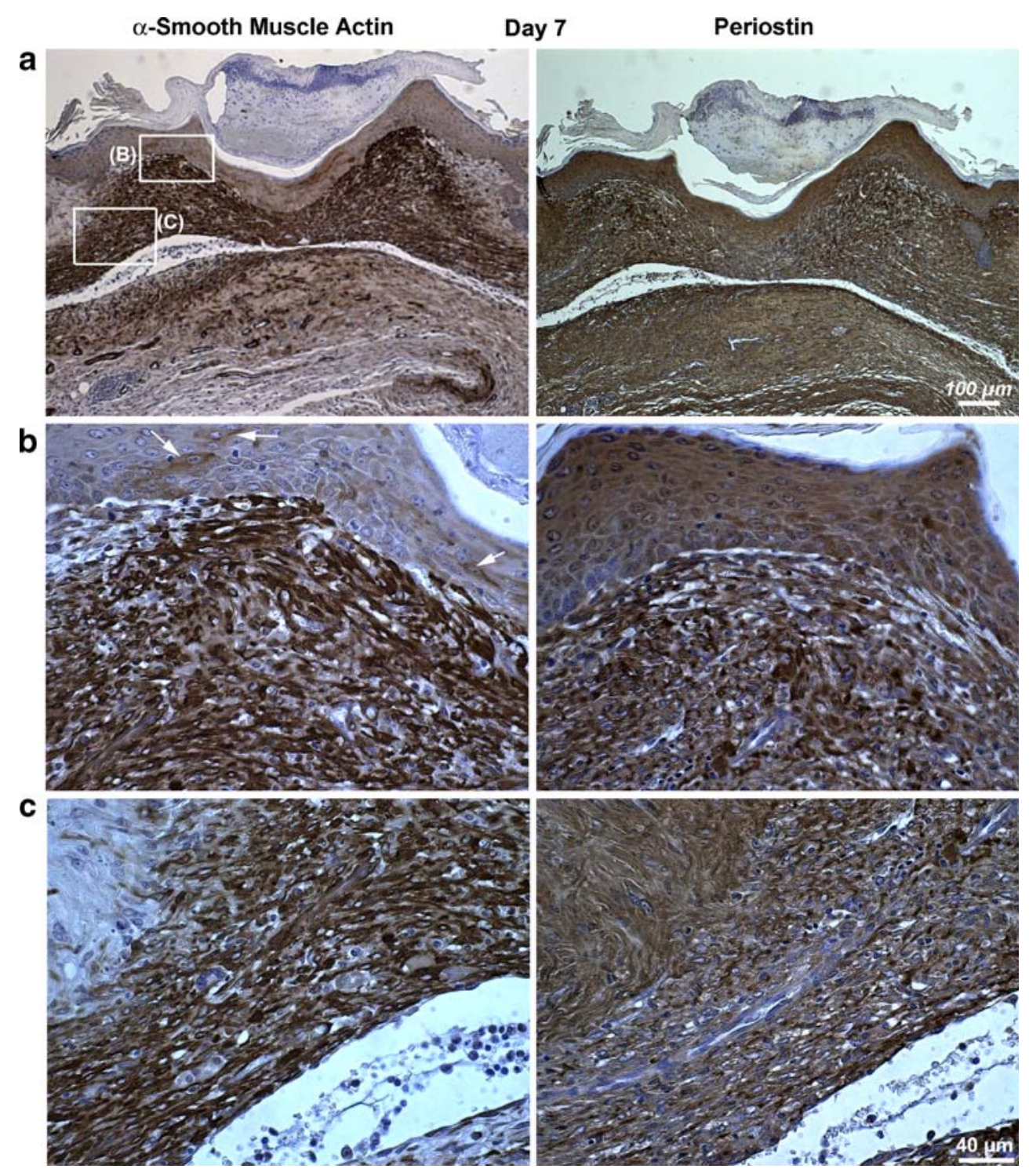

In healthy human skin, periostin expression is clearly associated with keratinocytes and dermal fibroblasts (Fig. 1). Interestingly, we did not detect periostin reactivity in the extracellular matrix of healthy dermis, suggesting it is unlikely abundant expression of periostin is required for maintenance of tissue homeostasis. However, the marked switch of periostin protein localization from cells to the ECM in pathological remodeling (nevus) compared to healthy skin, suggests that periostin plays a role in remodeling of tissues in response to pathological insult. Periostin expression is now known to be prevalent in many pathologies including cancer (Bao et al. 2004; Gillan et al. 2002; Ruan et al. 2009; Sasaki et al. 2001), bone marrow fibrosis (Oku et al. 2008), and cardiac hypertrophy and remodeling (Oka et al. 2007). In cancer, periostin has been shown to increase both cell motility (Gillan et al. 2002) and cell survival (Bao et al. 2004). Classed as a matricellular protein (Norris et al. 2008a), periostin has been shown to interact with cells through $\alpha \mathrm{V} \beta 3$ and $\alpha \mathrm{V} \beta 5$ integrins (Gillan et al. 2002), with subsequent activation of downstream targets including, but not limited to the Akt/Protein Kinase B pathways (Bao et al. 2004). Akt/Protein Kinase B pathways are particularly associated with cell cycle progression (Yun et al. 2009), potentially implicating ECMassociated periostin with proliferation. Interestingly, periostin has been previously shown to induce proliferation of polycystic kidney cells through $\alpha \mathrm{V}$ integrins (Wallace et al. 2008), and as proliferation of fibroblasts is an integral part of wound repair, it is possible that periostin mediates cell division. Future experiments will assess if extracellular periostin induces proliferation of dermal fibroblasts.

To further investigate the role of periostin in skin homeostasis and remodeling, we utilized the wellestablished excisional full thickness dermal wound repair model in mice (DiPietro et al. 1995). Periostin protein appeared in the provisional matrix at 3 days, but was most 
prominent at 7 days post wounding. The appearance of periostin was concurrent with an increase in $\alpha$-SMA positive fibroblasts, the cells responsible for contraction of wounds and scarring (Hinz 2007). To our knowledge, this is the first report that periostin is associated with myofibroblasts in dermal wound repair. Previous studies have identified that periostin expression is significantly higher in keloid or hyperplastic scars compared with normal skin (Wang et al. 2007). Furthermore, presence of periostin correlated with higher levels of transforming growth factor beta-1 (TGF- $\beta 1)$ in keloid scars, suggesting that periostin may be regulated by TGF- $\beta 1$. Regulation of periostin by TGF- $\beta$ isoforms has been confirmed in periosteum (Horiuchi et al. 1999), periodontal ligament (Horiuchi et al. 1999; Rios et al. 2008), and recently in the atrioventricular valve(Norris et al. 2009). Interestingly, differentiation of fibroblasts into myofibroblasts is also known to be regulated in part by TGF- $\beta$ (Tuan et al. 1996), opening the possibility that the expression of $\alpha$-SMA and periostin occur simultaneously due to the presence of TGF$\beta$ in the wound bed. Whether periostin protein is required for myofibroblast differentiation in dermal wounds has yet to be determined, although previous studies of the atrioventricular valve identified that periostin is essential for differentiation of mesenchyme to $\alpha$-SMA-containing myofibroblasts (Norris et al. 2008b; Norris et al. 2009).

Periostin reactivity in the nucleus was evident in the human keratinocytes and a subset of murine keratinocytes in healthy skin. Nuclear localization of periostin has been previously reported in carcinoma cells from a subset of patients $(12 \%)$, where nuclear localization correlated with tumour size (Puglisi et al. 2008). Whether periostin localization to the nucleus has any functional significance has not yet been determined. To date, it is known that alternate splicing of periostin results in four isoforms (Horiuchi et al. 1999), with only isoform four actually being secreted into the ECM (Simon J. Conway, personal communication). It is possible that depending on splicing, certain isoforms are present, some which may localize with the nucleus, others with the ECM. Further experiments will investigate the expression of each isoform in healthy and pathological tissues.

In conclusion, periostin is expressed at basal levels in healthy skin, where it likely plays a role in tissue homeostasis. Furthermore, induction of ECM remodeling, whether as a result of pathological insult (nevus) or experimentally induced (punch wound) changes the localization of periostin from the intracellular to extracellular compartment. It is possible that periostin is required in the ECM, stimulating remodeling of the matrix by directly influencing cell adhesion and resulting cell behaviour. This study provides further compelling evidence that periostin functions as a matricellular protein.
Acknowledgements The authors would like to thank Dr Andrew Leask, Dr Tom Daley and Dr Mark Darling for technical advice and helpful discussion on histological analysis. This work was funded by Schulich Medicine and Dentistry, and the Canadian Institutes of Health Research IMHA operating grants (IMH-94010) to D. W. Hamilton.

Open Access This article is distributed under the terms of the Creative Commons Attribution Noncommercial License which permits any noncommercial use, distribution, and reproduction in any medium, provided the original author(s) and source are credited.

\section{References}

Agren MS, Werthen M (2007) The extracellular matrix in wound healing: a closer look at therapeutics for chronic wounds. Int J Low Extrem Wounds 6:82-97

Bao S, Ouyang G, Bai X, Huang Z, Ma C, Liu M, Shao R, Anderson RM, Rich JN, Wang XF (2004) Periostin potently promotes metastatic growth of colon cancer by augmenting cell survival via the Akt/PKB pathway. Cancer Cell 5:329-339

Basu A, Kligman LH, Samulewicz SJ, Howe CC (2001) Impaired wound healing in mice deficient in a matricellular protein SPARC (osteonectin, BM-40). BMC Cell Biol 2:15

Butcher JT, Norris RA, Hoffman S, Mjaatvedt CH, Markwald RR (2007) Periostin promotes atrioventricular mesenchyme matrix invasion and remodeling mediated by integrin signaling through Rho/PI 3-kinase. Dev Biol 302:256-266

Chen YF, Feng JA, Li P, Xing D, Ambalavanan N, Oparil S (2006) Atrial natriuretic peptide-dependent modulation of hypoxiainduced pulmonary vascular remodeling. Life Sci 79:13571365

Chen Y, Leask A, Abraham DJ, Pala D, Shiwen X, Khan K, Liu S, Carter DE, Wilcox-Adelman S, Goetinck P et al (2008) Heparan sulfate-dependent ERK activation contributes to the overexpression of fibrotic proteins and enhanced contraction by scleroderma fibroblasts. Arthritis Rheum 58:577-585

Cowin AJ, Kallincos N, Hatzirodos N, Robertson JG, Pickering KJ, Couper J, Belford DA (2001) Hepatocyte growth factor and macrophage-stimulating protein are upregulated during excisional wound repair in rats. Cell Tissue Res 306:239-250

Desmouliere A, Chaponnier C, Gabbiani G (2005) Tissue repair, contraction, and the myofibroblast. Wound Repair Regen 13:7-12

DiPietro LA, Polverini PJ, Rahbe SM, Kovacs EJ (1995) Modulation of JE/MCP-1 expression in dermal wound repair. Am J Pathol $146: 868-875$

Elola MT, Wolfenstein-Todel C, Troncoso MF, Vasta GR, Rabinovich GA (2007) Galectins: matricellular glycan-binding proteins linking cell adhesion, migration, and survival. Cell Mol Life Sci 64:1679-1700

Erkan M, Kleeff J, Gorbachevski A, Reiser C, Mitkus T, Esposito I, Giese T, Buchler MW, Giese NA, Friess H (2007) Periostin creates a tumor-supportive microenvironment in the pancreas by sustaining fibrogenic stellate cell activity. Gastroenterology 132:1447-1464

Gabbiani G (2003) The myofibroblast in wound healing and fibrocontractive diseases. J Pathol 200:500-503

Gillan L, Matei D, Fishman DA, Gerbin CS, Karlan BY, Chang DD (2002) Periostin secreted by epithelial ovarian carcinoma is a ligand for alpha(V) beta(3) and alpha(V) beta(5) integrins and promotes cell motility. Cancer Res 62:5358-5364

Hamilton DW (2008) Functional role of periostin in development and wound repair: implications for connective tissue disease. J Cell Commun Signal 2:9-17 
Hinz B (2007) Formation and function of the myofibroblast during tissue repair. J Invest Dermatol 127:526-537

Horiuchi K, Amizuka N, Takeshita S, Takamatsu H, Katsuura M, Ozawa H, Toyama Y, Bonewald LF, Kudo A (1999) Identification and characterization of a novel protein, periostin, with restricted expression to periosteum and periodontal ligament and increased expression by transforming growth factor beta. J Bone Miner Res 14:1239-1249

Jarvelainen H, Puolakkainen P, Pakkanen S, Brown EL, Hook M, Iozzo RV, Sage EH, Wight TN (2006) A role for decorin in cutaneous wound healing and angiogenesis. Wound Repair Regen 14:443-452

Kuhn B, del Monte F, Hajjar RJ, Chang YS, Lebeche D, Arab S, Keating MT (2007) Periostin induces proliferation of differentiated cardiomyocytes and promotes cardiac repair. Nat Med 13:962-969

Latijnhouwers MA, Bergers M, Van Bergen BH, Spruijt KI, Andriessen MP, Schalkwijk J (1996) Tenascin expression during wound healing in human skin. J Pathol 178:30-35

Leask A, Shi-Wen X, Khan K, Chen Y, Holmes A, Eastwood M, Denton CP, Black CM, Abraham DJ (2008) Loss of protein kinase $\mathrm{C}$ \{epsilon\} results in impaired cutaneous wound closure and myofibroblast function. J Cell Sci 121:3459-3467

Lie-Venema H, Eralp I, Markwald RR, van den Akker NM, Wijffels MC, Kolditz DP, van der Laarse A, Schalij MJ, Poelmann RE, Bogers AJ et al (2008) Periostin expression by epicardiumderived cells is involved in the development of the atrioventricular valves and fibrous heart skeleton. Differentiation 76(7):809-819

Midwood KS, Williams LV, Schwarzbauer JE (2004) Tissue repair and the dynamics of the extracellular matrix. Int J Biochem Cell Biol 36:1031-1037

Norris RA, Borg TK, Butcher JT, Baudino TA, Banerjee I, Markwald RR (2008a) Neonatal and adult cardiovascular pathophysiological remodeling and repair: developmental role of periostin. Ann N Y Acad Sci 1123:30-40

Norris RA, Moreno-Rodriguez RA, Sugi Y, Hoffman S, Amos J, Hart MM, Potts JD, Goodwin RL, Markwald RR (2008b) Periostin regulates atrioventricular valve maturation. Dev Biol 316:200-213

Norris RA, Potts JD, Yost MJ, Junor L, Brooks T, Tan H, Hoffman S, Hart MM, Kern MJ, Damon B et al (2009) Periostin promotes a fibroblastic lineage pathway in atrioventricular valve progenitor cells. Dev Dyn 238(5):1052-1063

Oka T, Xu J, Kaiser RA, Melendez J, Hambleton M, Sargent MA, Lorts A, Brunskill EW, Dorn GW 2nd, Conway SJ et al (2007) Genetic manipulation of periostin expression reveals a role in cardiac hypertrophy and ventricular remodeling. Circ Res 101:313-321

Oku E, Kanaji T, Takata Y, Oshima K, Seki R, Morishige S, Imamura R, Ohtsubo K, Hashiguchi M, Osaki K et al (2008) Periostin and bone marrow fibrosis. Int J Hematol 88:57-63
Puglisi F, Puppin C, Pegolo E, Andreetta C, Pascoletti G, D’Aurizio F, Pandolfi M, Fasola G, Piga A, Damante G et al (2008) Expression of periostin in human breast cancer. J Clin Pathol 61:494-498

Puolakkainen PA, Bradshaw AD, Brekken RA, Reed MJ, Kyriakides T, Funk SE, Gooden MD, Vernon RB, Wight TN, Bornstein P et al (2005) SPARC-thrombospondin-2-double-null mice exhibit enhanced cutaneous wound healing and increased fibrovascular invasion of subcutaneous polyvinyl alcohol sponges. J Histochem Cytochem 53:571-581

Reed MJ, Puolakkainen P, Lane TF, Dickerson D, Bornstein P, Sage EH (1993) Differential expression of SPARC and thrombospondin 1 in wound repair: immunolocalization and in situ hybridization. J Histochem Cytochem 41:1467-1477

Rios HF, Ma D, Xie Y, Giannobile WV, Bonewald LF, Conway SJ, Feng JQ (2008) Periostin is essential for the integrity and function of the periodontal ligament during occlusal loading in mice. J Periodontol 79:1480-1490

Ruan K, Bao S, Ouyang G (2009) The multifaceted role of periostin in tumorigenesis. Cell Mol Life Sci Mar 24. [Epub ahead of print]

Sasaki H, Lo KM, Chen LB, Auclair D, Nakashima Y, Moriyama S, Fukai I, Tam C, Loda M, Fujii Y (2001) Expression of periostin, homologous with an insect cell adhesion molecule, as a prognostic marker in non-small cell lung cancers. Jpn J Cancer Res 92:869-873

Shimazaki M, Nakamura K, Kii I, Kashima T, Amizuka N, Li M, Saito M, Fukuda K, Nishiyama T, Kitajima S et al (2008) Periostin is essential for cardiac healing after acute myocardial infarction. J Exp Med 205(2):295-303

Tilman G, Mattiussi M, Brasseur F, van Baren N, Decottignies A (2007) Human periostin gene expression in normal tissues, tumors and melanoma: evidences for periostin production by both stromal and melanoma cells. Mol Cancer 6:80

Tuan TL, Song A, Chang S, Younai S, Nimni ME (1996) In vitro fibroplasia: matrix contraction, cell growth, and collagen production of fibroblasts cultured in fibrin gels. Exp Cell Res 223:127-134

Wallace DP, Quante MT, Reif GA, Nivens E, Ahmed F, Hempson SJ, Blanco G, Yamaguchi T (2008) Periostin induces proliferation of human autosomal dominant polycystic kidney cells through alphaV-integrin receptor. Am J Physiol Renal Physiol 295: F1463-F1471

Wang Q, Nie FF, Zhao X, Qin ZL (2007) The expression of periostin in hyperplasic scars and the relations to TGF-betal and its receptors. Zhonghua Zheng Xing Wai Ke Za Zhi 23:229-232

Yun SJ, Tucker DF, Kim EK, Kim MS, Do KH, Ha JM, Lee SY, Yun J, Kim CD, Birnbaum MJ et al (2009) Differential regulation of Akt/protein kinase $\mathrm{B}$ isoforms during cell cycle progression. FEBS Lett 583:685-690 